\title{
Project over: nocturnal enuresis and urinary disorders
}

\author{
Giuseppe Ragnatela1*, Marina Picca ${ }^{2}$, Lorenzo Cresta ${ }^{3}$, Mario Fama ${ }^{4}$, Carmela Lo Giudice ${ }^{5}$, Angela Pasinato ${ }^{6}$, \\ Marco Sequii ${ }^{8}$, Pier Luigi Tucci ${ }^{7}$ \\ From 70th Congress of the Italian Society of Pediatrics, Joint National Meeting SIP, SICuPP, SITIP \\ Palermo, Italy. 11-14 June 2014
}

\section{Background}

"Enuresis " also known as bedwetting or night-time incontinence is the inability to control urination during sleep $[1,2]$. Mono-symptomatic enuresis (MNE) is the only night-time incontinence and "not mono-symptomatic enuresis" (NMNE) is also the daytime urinary disorders. Bedwetting is a disorder that affects the development of children personality and interferes with social relationships of children and their family.

\section{Aim}

Primary endpoint is to estimate the prevalence of enuresis in patients aged 5 to 14 years, to evaluate the awareness of the problem by the family [3], to assess the discomfort experienced by patients and then to look for the presence of co-factors.

\section{Methods}

The study, promoted by SICuPP (Italian Society of Pediatric Primary Care), was based on a questionnaire filled by the parents of children enrolled by 75 pediatricians from three different regions (Veneto, Tuscany and Puglia).

\section{Results}

We evaluated 3165 children (1618 males and 1547 females). The enuresis is present in 262 children $(8.2 \%$ of the study); the prevalence was $16.5 \%$ at 5 years $10.5 \%$ and $6 \% \mathrm{NMNE} / \mathrm{MNE}$ ) and decreases with age up to $4.6 \%$ (2.6\% and 2\% NMNE/ MNE) at the age of 13 years; these data agree with other epidemiological studies . Familiarity and sleep disorders are potential risk factors. Only $33 \%$ of parents tell the problem to the pediatrician: $67.8 \%$ of the parents don't speak of it because they consider it

${ }^{1}$ ASL BAT Barletta, Italy

Full list of author information is available at the end of the article unimportant, 2.7\% because they are "ashamed", 29.5\% for "other reasons". Only 32 patients with enuresis (12.2\%) were in treatment. $21.8 \%$ of parents think that enuresis "very emotionally involved" their child, $8.5 \%$ think that the child is "very limited" in its activities with classmates, $8.7 \%$ think that the child is "very concerned" about his health. 33.3\% consider bedwetting problem "very important" for the family organization, $24.7 \%$ consider that it restricts greatly the activity of the child with classmates, $17.3 \%$ is "very concerned" about the health of the child, and finally $11 \%$ think that bedwetting is something to be "very ashamed" of.

\section{Conclusions}

Preliminary data show that bedwetting is a "masked" disease. It is important to look for and recognize the problem, to improve the quality of life of patients and their families

\section{Authors' details}

${ }^{1}$ ASL BAT Barletta, Italy. ${ }^{2}$ ASL Milano, Italy. ${ }^{3}$ ASL Genova, Italy. ${ }^{4}$ ASL 17 Monselice-Este, Italy. ${ }^{5}$ ASP 6 Palermo, Italy. ${ }^{6}$ ASL Vicenza, Italy. ${ }^{7}$ ASL 10 Firenze, Italy. ${ }^{8}$ Mario Negri Institute for Pharmacological Research, Milan, Italy.

Published: 11 August 2014

\section{References}

1. Vande Walle J, Ritting S, Bauer S, Eggert P, Marschall-Kehrel D, Tekgul S: Practical consensus guidelines for the management of enuresis. Eur $J$ Pediatr 2012, 171:971-983.

2. Nevéus T: Nocturnal enuresis - theoretic background and practical guidelines. Pediatr Nephrol 2011, 26:1207-1214.

3. Yeung CK, Sihoe JD, Sit FK, Bower WF, Sreedhar B, Lau J: Characteristics of primary nocturnal enuresis in adults: an epidemiological study. BJU Int 2004, 93:341-345.

doi:10.1186/1824-7288-40-S1-A81

Cite this article as: Ragnatela et al:: Project over: nocturnal enuresis and urinary disorders. Italian Journal of Pediatrics 2014 40(Suppl 1):A81.
() Biomed Central

(c) 2014 Ragnatela et al; licensee BioMed Central Ltd. This is an Open Access article distributed under the terms of the Creative Commons Attribution License (http://creativecommons.org/licenses/by/4.0), which permits unrestricted use, distribution, and reproduction in any medium, provided the original work is properly cited. The Creative Commons Public Domain Dedication waiver (http://creativecommons.org/publicdomain/zero/1.0/) applies to the data made available in this article, unless otherwise stated. 